遠隔探知方式について一論評

松野 久也*

\title{
On the Remote Sensing System-A Review
}

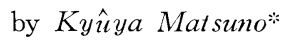

はじめに ごく最近(1966年 9 月20日), アメリカ合 衆国内務長官 Stewart L. Udall 氏は, 衛星による地球 表面の反覆観察計画を公表した。この計画は“EROS (Eatrh Resources Observation Satellites)”計画と呼 ばれ，航空宇宙局 (NASA) とその他の政府機関との 協同のもとに推進されることになっている。 Stewart L. Udall 氏は, 1966 年, Photogrammetric Engineering 誌の第31巻, 第 1 号に “Resources Understanding-A Challenge to Aerial Methods と題する論 説を発表し，宇宙からの探査法を含めた広い意味の空 中探査法の現状ならびに将来の発展について論評し， これに対する一般の関心を呼び，かつ科学技術者に対 して，その装置ならびに方法の開発，改良に対して， 激励を与えていることは, すでに本誌第 5 卷, 第 2 号 の文献紹介の欄で, 紹介した通りである。

現在のところ，EROS衛星の打上げ時期については 明らかにされていないが, 最初の衛星には, 少くとも 2 台のテレビカメラが搭載され, そのうちの 1 台は, 海陸掞よび植物の分死に関して最大の情報が得られ， 他の 1 台は水の対して最大の透過を得るような波長域 で動作することが期待されている。

この計画の調整官として, わが国に拈いてもよく知 られているアメリカ合衆国地質調査所の William A. Fischer 博士が加わっているのである。

EROS計画とは，どんな目的をもつものであるか？ また，どんな遠隔感応装置が搭載されるのであろろか ?これら雨点は, とくに空中写真と言う現在もっとも 広く用いられている遠隔探知方式を利用し，あるいは これを通して, 地球に関する科学・工学および資源の 探査に従事している私たちにとって, 極めて興味が深 い問題である。

ごく最近(1967年 3 月10日), アメリカ合衆国地質調 査所長 William T. Pecora 博士は, 米国測量・作困

* 通商産業省地質調査所 Geological Survey of Japan
会議(American Congress on Surveying and Mapping) の第27回年次大会に拈いて，“Surveying the Earth's Resources from Space” と題する講演死行ない, 人工 衛星からの調査とこの方法の利点ならびに予想される 遠隔探知方式の応用について, 概説している。この種 の内容の講演が，他の会合に招いても，行なわれてお り，アメリカ合州国政府機関とくに地質調査所が, EROS計画に如何に力を注いでいるかがうかがわれる。

Pecora博士は, その講演の冒頭に概略次のような趣 旨のことを述べている。すなわち「資源に対する需要 の著しい増大に対し，われわれは資源探査を促進する 手段を見付出さなければならない。これに対して空中 写真と空中物理探査技術が，世界中で資源に関する知 識を獲得する速度を非常に增大させ，この点大きく貢 献している。しかしながら，われわれが直面している 問題は非常に大きく, 既存の機器拉よび技術をさらに 広く利用しても, 追いつかない位である。幸いにも, 今や航空機招よび地球軌道上の人工衛星に搭載した遠 隔探知装置を利用することによって，との間の開きの ある程度を埋めることができるのである。」

ここで大きな期待がかけられているのは, 遠隔探知 装置と人工衛星である。

\section{遠隔探知に関する世界の歩み}

遠隔探知装置とは, 航空機あるいは人工衛星上から, 地球上のいるいるなデー夕を得るために用いられる装 置であって, 既に述べた通り空中写真は, 現在もっと も広く用いられている方式の一つである。空中写真に は, パンクロ写真, 赤外線写真, カラ一写真, 赤外・ カラー写真, さらに最近では, レンズを 9 個備え, 一 度にいろいるな波長域の写真を撮影する多波長带域写 真 (multi-spectral photography) などが用いられて いる。これは可視域の波長帯域および近赤外域の波長 特よびその一部を使用するものであるが，最近では， とくにアメリカ合衆国に特いて中間赤外線の波長域を 利用した赤外放射温度測定あるい㤸外線映像装置に 
よる被写体の表面の温度分布の観察が行なわれて沶 り，さらに長い波長のレーダー波を利用するレーダー 写真が実用段階に来ている。さらに, マイクロ波, 才 一デイオ(可聴)波, ラジオ波, 紫外線などの領域の探 知装置に対する研究斥行なわれている。

以上のほか, 磁気探査, 放射能探査などの地球物理 学的方法のなかで空中方式に応用できるものも, これ ら遠隔探知方式に含められるものである。

ここでは普通一般に言われる空中物理探査法は別と して, 第二次大戦から以後, とくに最近数年間に, 新 しく改良された探知装置の発達は著しく，このような 傾向は今後も続くことは疑!、のないところであるう゚ これに対して, これら探知装置の地球科学の分野への 応用は, 遺憾ながら非常にテンポが遅いのである。こ のような観点から,米国に扮いて1961年1月, Nationa Academy of Science, National Research Council so よび Office of Naval Research Geographyの代表か らなる委員会に拈いて, 地球科学の分野に拈けるもっ と進歩した効率のよいデータ獲得法と解釈に関する技 術の推進が必要なことが討議され, 環境の遠隔探知法 に関する強力な研究が勧告されたのである。そして, その12月, この勧告に沿った小委員会が生れ, 活動を 開始している。

そして1962年の 2 月に, 第 1 回の環境の遠隔探知に 関するシンポジウムが開催され，同年10月に第 2 回, 1964年10月に第 3 回のシンポジウムが開かれている。 第 3 回のシンポジウムには, ざっと 90 以上の報告が提 出され, これらのうち, ざっと55は, 現在さらに将来 に执いて予想される研究計画を論じて括り，これらの ろち多くの報告は, 遊星の研究, 地球の探查, 天文学 抢よび海洋学などの分野に沶ける人工衛星の使用を考 えているものであった。その他, 新しい装置括よび遠 隔探知装置によって得られたデータの解釈に関する報 告が数多くみられ, その範囲は多带域写真, 赤外線映 像扮よびレーダー写真などにわたっている。この第 3 回遠隔探知シンポジウムに提出された話題は, アメリ カ写真測量学会の会員にとっても非常に重要な問題を 含んで扣り，ミシガン大学の Joseph O. Morgan 少 よび Virginia L. Prentice 兩氏が招待せられている。 このシンポジウムの内容については, 彼らが詳しく論 評していることについては, 既に本紙第 5 巻, 第 3 号 で紹介された通りである。

一方，1964年，リスボンに括ける国際写真测量学会 第 8 回年次大会に括いて, 遠隔探知技術として, 赤外 線映像括よびレーダー写真が水理学上の目的に有効な ことが，米国の科学者によって紹介せられ，これらが “映像記録技術”として次の1968年のロザンヌに拈け る大会までの主要な追究主題の 1 つとしてとりあげら
れるよろ決議された。そして，1968年のロザンヌ大会 では,この主題の報告者として, 前述の William A. Fischer 博士が選出され, “Collection of Information for Photointerpretation, Obtained from Any Airborne Vehicles”と題する報告が提出され，これを中 心に畤論が進められる予定となっている。

こうして, 可視域を越えた波長域を利用する遠隔探 知方式が国際的に一・連の状況は不明であるが正式に取上げられるようになったのであるが，この分 野の指導的地位にある米国では, これら坡隔探知方式 を人工衛星に応用する計醉が進められるところまで来 て扣り，关の進歩の非常に早いことに驚かされるので ある。

わが国では，地質調查所がすでに1961年頃から，赤 外線映像が地球科学の分野に応用して大きな効果が期 待できることに注目し，1954年頃から赤外線応用装置 の研究・開発を行なって来た日本電気株式会社の技術 陣と1964年以来連けいをとりつつ，空中から地表面を 走查するバッシブ赤外線映像装置を開発し，これを地 球科学に役立たせようとしている。そして，1966年， 最初の空中用パッシブ赤外線撮像装置を試作してい る。また, 海上保安庁では, 赤外線放射温度計を海況 調査に応用している。

\section{—遠隔探知方式の応用とその現状}

ここ数年，とくに第 3 回環境遠隔探知シンポジウム 以来, 遠隔探知装置ならびにその応用に関する報告が 非常に多い。そして, その地球科学・環境科学ならび に土学, さらに他の多くの分野に応用して大きな偉力 を示すことが次々と実証されつつある。まえにも述べ た通り,この分野で指導的立場にあるのは, アメリカ 合衆国であって, 種々の装置拈よびその進歩の見透, 応用範囲さらに予想される応用について内務長官をは じめ, 多くの主要な地位にある人も論評を加え, 一段 の進歩を推進しているように見受けられる。

これらの研究には, 軍は勿論のこと, 種々の政府機 関, 大学, 民間会社など非常に広範囲にわたるものが 従事している。これらの成果についてすべてを集録論 評を加えることはとこも不可能なことであるので, 前 述の Pecora 博士の講演, ならびに7月末アメリカ合 衆国地質調榃所の F ischer 博士より贈られた最新の資 料を中心にして，現状を見渡してみることにする。

アメリカ合衆国地質調查所では, ここ 2 年間, 航空 宇宙局(National Aeronautics and Space Administration）との協力のもとに，普通の航空機上から得ら れる遠隔装置のデータの利用の可能性と実用性とを研 究して来た。この研究の究極の目的は,ずっとこみ入 った遠隔探知装置を積込九た人工衛星から, 地球上の 
天然資源に関するデータを得る技術の開発にあるが， これつの実験の結果は, 遠隔探知装置によって天然資 源を調查し評価することができることを如実に示して い令。

こニミ，従来の研究および種々の実験結果から, 従 来の贸中物理探査法老除いて, 現段階で有效な遠隔探 知才圪と考えられるものは, 各種空中写真は勿論とし $\tau$, 多波長带域写真, 赤外線放射測定, 赤外線映像, レーダー写真 (あるいは映像)，紫外線映像などであ る。

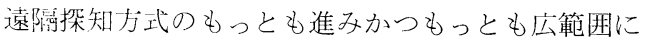
利用されているパンクロ写真, 赤外線写真, カラー写 真, 赤外カラー写真はど空中写真による方式について は,会貣諸兄姉のよく知って招られるところであって， ここに説明の必要はないであろう。ただし，この写真 の中ー゙, 最近新しい方式として目につくのは多波長帯 域力メラの使用である。これは，9個のレンズをもっ た力マラを使用するものであって，目的によってフィ ルムとフィルターの特殊な組合せによって，同時に同 一被体について，いるいるな波長带域の映像を得よ うとする斗のである。この方式によって得られるデー 夕は非常に多量なものが期待されるが，その評洒につ いて，今のところ報告されたものは少い。

現段階で，もっとも進み，多くの実験ならびに実際 に応用されつつあるのは，赤外線放射湘定抢よび赤外 線映像である。すべての物体は， 0.72 ミクロンから 1,000 ミクロンの波長带域の赤外線を放射している。 ある物体の赤外線放射エネルギーは，その絶対温度の 4 乗に比例しかつその放射率に比例する。したがって， 地物の赤外線放射エネルギーと放射率がわかれば，そ の地物つ温度を決定できる。

最近，携带用の赤外線放射温度計の開発に伴って， 航空機上から航空機の航跡に沿って，連続的に地表あ るい汢水面の温度を連続的に测定し，地表あるいは 水面の温度分布の作四が可能となり，各方面で実用に 供されている。すなわち，メキシコ湾流の空中から の温度测定, Dayton 大学によるカリフォルニヤの山 地中の湖水の水面温度, アメリカ合衆国の Bureau of Sport Fisheries and Wildlfe の Tibuiron Marine Laboratory によるロスアンゼルス近海の水温测定 $\left(1^{\circ} \mathrm{C}\right.$ 間隔の等温線による温度分布図の作困 $)$ など枚挙 にい上まない程である。わが国でも, 海上保安庁が 1965年赤外放射温度計を試作し, 沖合海況和よび海流 の調柰を実施している。また本年, 7 月 31 日, 朝日新聞 が赤外線放射温度計による東京の市街地执よび富士山 の空中心らの温度測定について報じたことについて， 読者の中に御承知の方々も少くないものと考元られ
る。

赤外線放射温度計による温度测定は, 点あるいは测 線に沿った测定に限られる。この赤外線放射温度計の 瞬間視野を小さくしぼり, スボットで物体の表面を走 查し, 放射エネルギー強度圭映像装置が開発されてい る。この装置によって得られた映像のトーンの変化は, 温度の変化に対応する。この方式は地表面あるいは水 面の温度分布のマッピングに非常に大きな效果を発揮 する。

1963年 2 月から 3 月にかけてアメリカ合衆国地質調 査所によって実施されたハワイのキラウエア火山の赤 外線調査は，火山活動に関連する目にみえない地温異 常のマッピングのほか，海岸線付近における海底涌泉 の探知と言う付録屯でついて，非常な效果をおさめ， この式の偉力を多くの人々に認識させたのである。 この調査の結果は活火山周辺の地温分布の変化を観測 することによって，爆発予知の警報を出すための一つ の手がかりが得られるものと考元られ，反覆観測の必 要なことが痛感される。

一方，この方式は地熱開発のための調査にも有効な ことが考えられ，Yellow Stone Parkの有名な間けつ 泉周辺々の他で，実験が行なわれた。アイスランドの Surtsey 火山地域の調查では, 従来知られていた地温 異常は勿論のこと，今まで知られていなかった同様な 異常をマッピングすることができた。ここで非常に興 味あることは，ある場合には普通の空中写真の方が非 常にこの種の調査に有效なことである。すなわち, 積 雪時の空中写真上に，地温異常のあるところは，雪が とける結果，暗いトーンで記録されることである。こ の事実は，我が国の地質調査所が1965年那須火山の殺 生石で, 地温分布の観測を始めて実施した際，実験に 先立って俄雪があって, その融雪のパターンから予め, 地温異常をカラー写真に記録することができ，赤外線 映像の結果をチェックすることができたのと全く同じ である。

実際の例は未だ報告されていないが，ある型の鉱床 探査への応用が考えられている。すなわち, 鉱物が酸 化する場合，かなりの反応熱を出すことである。例え ば，アラスカに括ける銅の硫化鉱休であって，その酸 化の際の反応熱によって，それをカバーする永久凍土 がとかされている場合である。

赤外線映像は, とくに水面が一様な散乱面と考元ら れることから，水理工学上多くの問題の解決に非常に 大きな効果があることが実証されて扣り，また期待さ れる。八ワイは火山島であるため，かなりの降雨量が あるにもかかわらず，水が地下に滲透し，全く河川が なく, 水は貴重品である。前述の通り, 海水温度と地 
下水の温度差から，海岸における海底湧泉の位置とと れが海水中に分散して行くパターンが，前述のアメリ 力合衆国地質調査所の赤外線調査から探知され，呀井 位置の決定に重要な資料を与えている。

もう一つの問題は, 塩水楔の河川水中への侵大であ る。普通, この調査は, 水のサンプルをとり, 塩化物 の量を測定し，これを地図上にプロットし，等值線を 描き塩水楔の形，大きさ，位置を決定するのである。 赤外線映像装置を用いれば, 海水と河川水の温度差か ら，目に見える形で塩水楔の形，大きさ，位置を容易 に決定できる。アメリカ合衆国地質調查所は，マ少チ ュウセッツ州と協同のもとに, Merimac川の河口付近 の塩水と河川水とのぶつかり合う所のマッビングを行 なっている*。この調査は時間毎の変化を知るために反 覆撮像が行なわれている。このデータは, 市の水道の 供給に重要な資料を提供し, 内湾の漁業にも貢献する ものであり, 合衆国では, この種の調査を, 東海岸に ついて広く行な打うとしているのである。

非常に特殊な応用であるが，炭釯の坑内火災に由来 する災害の原因調査である。合衆国釯山局の要請に基 いて，同地質調查所は，ペンシルヴァニヤ州のScranton の炭鉱地域の空中赤外線調査を実施した。ここで は, 坑内火災によって, 有毒ガスが発生し, これが上 盤の岩石中の割目を通って住宅地域に湧き出し, 数人 の死者を出したのである。この調査によって，坑内火 災の位置に直接関係のある地温異常地をマッピングす ることができたのである。

アクティブマイクロウェーブ方式すなわちレーダー あるいはパッシブマイクロウエーブ方式によって, 地 表の地物のマイクロウェーブの反射あるいは放射の性 質をマッピングできる。サイドルッキング空中レーダ 一映像は, 昼夜晴雨にかかわらず，広大な地域の力バ 一できるすぐれた装置である。この装置によって，い くつかの岩石の型を区分することができ，構造の特徴 をマッピングすることができる。とくに地形㧍よび地 形にあらわれた構造の特徵が, 强調されて表現され, 小縮尺の平面図のマッピングに有効である゙*。水面は, マイクロウェーブに対しよい反射面となるため, 映像 上一様な暗いトーンとして表現されるため, 陸域と水 域の区分以外, 水の物理的, 化学的あるいは生物学的 性質の探相には役に立ちそろもない。

紫外線映像は，現在，アメリ力合衆国地質調查所㧍 よび航空宇宙局によって，その研究が推進され，空中 から実際に映像を得るところまで来ている。装置の走 査機構は, 赤外線映像装置と全く同じである。3,000

* この時の映鹪㧍よひ他の 1 例が筆者のものと賺られて来ている。

** San Fransisco 付近の San Andeas 断層を中心と古る区域 のレーター䀑等が箨者の手許にとどいている。
以下の短い波長の映像では，ある種の岩石が可視域の 麦真より，コントラストが強くあらわれることがはっ きりしている。しかしこの分野は，まだまだ研究在要 する段階にある。

\section{宇宙からの遠隔探知方式}

第 3 回環境遠隔探知シンボジウムに提出さ社た報告 中には，人工衛星の使用を考光ているものもかなり含 末れており，末た，最近では，地球資源観察衛星計画 (EROS Program) が進められつつある段階に来てい ることは既に述べた通りである。

人工衛星あるいは宇宙船からの観察のもっともすぐ れた点は

1）非常に広い範囲を一・度に観察できること。

2)世界中をカバー・゙きること。

3）韭常に早い速度であること。

4）反覆観祭が可能なこと。

5）一定の大陽角度で照明された映像を得ることが できること。

などがあげられる。

高度 150 マイルから 120 インチの焦点距離のカメラ を使用すれば, 1 ミリメートル当り 100 線の解像力をも つ写真上で, 地上の解像力は2.4フィートで女る之臬わ れる。この点は一応除外しても, 非常に広い範囲を一 枚の写真に扮さめることができるため, 一つつ造山带 あるいは堆積盆の全体を一度に観察することができ， 傾きの大きな斜写真あるいは極軌道上を飛翔寸る衛星 を利用すれば，世界全体をカバーすることができるの である。このような世界全体をカバーする速度も非常 に早い。すなわち, 極軌道上 300 マイルの高度ご飛烣 する衛星を利用すれば，僅か 4.5 日で全地球表面を力 バーすることができ，数ケ月あるいは 1 年におうぶ寿 命をもつ衛星を打上げることができれば，4.5 日の時 間間隔で地表の特徽の変化を観察できる。さらに，一 定の大陽角度で非常に広い範囲を瞬間的に記録するた め, 普通写真から作成されたモザイク写真のように, 写真毎のトーンの変化の調整の必要がないことが非常 に優れている。

このような人工衛星から，どのような遠隔探知が実 施でき，どのようなデータが得られるのであこうか， 以下 $2 \sim 3$ の例に触れてみよう。

人工衛星からの写真が，現に沢山撮影され，二れら がカプセルとともに回収され，あるいは，テレビ像と して送られて，新聞紙上あいはいるいるな出版物に 公表されている。これらの写真の利用法として，まず 最初にあげられるのが，地図作成である。地図は，い うまでもなく, 地質調査, 資源探査, 海洋調査, 水資 源調査, 土地利用調査, 都市計画, 道路計画关刀他, 
数えきれない程多くの調査計画にとって必須のもので ある。ところが, 現在のところ, 極地方やヒマラヤ山 脈のような山地など,世界の僻地の大部分については, 使用に耐える地図がないのである。したがって，世界 中の陸地について, 情報を得るための地図作成計画に もっとも重点が抎かれることは疑いのないところであ ろろ。この点, Gemini VII 号衛星から撮影されたフ ロリダのケープケネディ付近の写真上では, $1: 250,000$ の縮尺の地形図に盛りこまれた程度の地表の細部が読 みとれることが，この計画の可能性を示している。ま た人工衛星から得られた麦真は，非常に大きな範囲を カバーしており，しかもこれが瞬間的な記録であって， 普通の航空写真をもってしても到定到達できないよう な産密な同時性を示している。杂た, 前述のように非 常に早い速度で, 反覆撮影ができるため, 環境の条件, 地表の特徵, 資源, 人口, いろいろな自然現象および 人間の活動などの位置, 配列, 組合せなどの変化が判 読できるのである。したがって, アメリカ合衆国地質 調査所は, このような利点を重視し, 宇宙写真から 1968年に国土地四帳を出版しようと計画し, 目下編集 中である。また, Association of American Geographorとの協力のものと, タイムリ一な国土の土地利用 困を作成しようと言う計画も進行中である。この分野 に利用される写真は, 単飞宇宙写真と呼ばれるばかり でなく，とくに宇宙・時間写真 (space and time photography）と呼ばれ，これらを利用する写真測量 を同じく宇宙・時間写真測量 (space and time photogrammetry) と呼ばれるのである。このう式のもっと も優れた利点の一つは, 非常に広大な地域のデータを 小縮尺に圧縮して表現することができるのであって， 広い地域の予察的データを把握するのに, その迅速性 ばかりでなく経済性も, 極めて高いのである。

地球表面の約70\%が海洋であるが，この大部分は， 従来の方法で現地で調査することは実際には不可能で ある。た々え，航空機でその上空を飛ぶことができ， いろいろな情報を得ることがで主たとしても，との位 置付けと言う点で著しい困難がある。この点, 宇宙船 あるいは人工衛星からの調査が，偉力を発揮すること は疑いのないところである。現在, Nimbus 衛星から のメキシコ湾流の赤外線映像が, 海面温度の差の観察 と, 流れのパターンに関連する温度分布の観察の可能 なことを明らかにしている。この事実は，海流のパ夕 ーンおよびその時間的変化をはじめ, いろいろな海況 調査に重要な貢献をなすであろう。

以上，簡単に，人工衛星を利用した遠隔探知につい て紹介したが，Pecora博士も言っているように，これ らの利点は, 写真判読の価值を高め, そして, 非常に 高い精度で記録された普通の空中写真のデータの位置

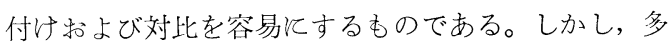
くの場合, 宇宙からのデータはあくまであ補助的なき のであって，普通の空中写真にとって代るものだはな w。

むすび 1967年7月24日，EROS計画の調整官であ る William A. Fischer博士より, William T. Pecora 合衆国地質調查所長の最近の 2 つの講演のテキストと 共に，赤外線映像をはじめ，種々の遠隔探知方式を論 じた論文を多数贈られた。これらはごく最近発表され たばかりのもので，7月18日にワシントンで投函さ秃 たものである。

これらに目を通してみて, 現在のアメリカ合衆国に 打ける遠隔探知方式の進歩と応用についての大略を知 ることができる。わが国では，やっと空中赤外線映像 あるいは赤外線放射温度計による遠隔探知が 2 3 の 機関によって取組まれはじめたばかりであるが，すで に気衰庁では，気象衛星からのデータを受信して，こ れを天気予報に利用して打り，日本放送協会によって 通信衛星を利用しての国際的なテレビ中継が行なわれ ている。また，地球資源観測衛星が，ごく近い将来に 打上げられ，これからのデータの利用も可能なことが 予想できないとは言えない。さらに，このような衛星 をわが国自身の手で打上げられることも期待できない わけではない。

ここ数年の間に，写真判読の範囲が可視域から長い 波長の側に拡げられ，李た，短い波長の方にも拡げら れつつある。さらに, 人工衛星から, 従来の航空機に よる方式に比べて，比べものにならない位の高い視野 からのデー夕蒐雄が実現している。そのためは, 種々 の遠隔探知方式が開発されつつあり，そのろちのある ものは，既に実用に供して大きな㗢きをしている。さ の一つ一つには，それぞれ特徴がある。したがのて， より多くの方式を併せ用いて，より多くのデータが得 られるのである。

これらに関して, アメリカ合衆国地質調査所長 Pecora博士の講演を軸にして, 遠隔探知方式の現状に ついて比較的平易に概説を試みた次第である。

すでに述べた通り, 最新の資料を, 早急に扮届け下 さった Fischer 博士の御厚意に報いるために，とりあ えずその要点でも会員諸兄姉に打知らせするのが最良 の法と考光, 筆をとった次第である。時日が切迫し ているため, 充分意を尽せなかったところあるいは棓 謬もあるかと思われるが，この点御容赦の程执願いす る次第である。

\section{文献}

Fischer, W.A.; Geologic Applications of Remote 
Sensors. (Manuscript).

Fischer, W.A., Davis, D.A. \& Sausa, T.M.: Fresh Water Springs of Hawaii from Infrared Images. Hydorographic Investigations Atlas HA-218, U.S. Geological Survey, 1966.

Hemphill, W.A., Fischer, W.A. \& Dornbach, J.E.: Ultraviolet Investigations for Lunar Missions. Advances in the Astronautical Sciences, Vol. 20.

Pecora, W.T.: Surveying the Earth's Resources from Space. 27 th Annual Meeting of the American Congress on Surveying and Mapping, Washington D.C., March

\section{海上保安庁 水路要報}

新潟海岸のいと波 佐藤奎吾 昭和 26 年 25 号

対景困と水路部式撮影機 佐藤富士達 昭和 28 年 38 号

深海潜水機による海底写真（東海号による第 1 回実 験報告）佐藤富士達 昭和 29 年 45 号

航空機からの斜写真による地形の略測法 山崎真義 昭和 29 年 40 号

潮流の空中写真測量法について 杉浦邦朗, 福島資 介 昭和 39 年 76 号

解析空中三角測量による測深基準点の展開（水路測 量における写真測量の利用 [1]）杉浦邦朗, 岩崎博, 束原和雄 昭和 39 年78号

渡海架空線の安全可航高の測定について（水路測量 に护写真測量の利用 [2]）小野弘平，杉浦邦朗 昭和 40 年 79 号
10, 1967.

Pecora, W.T.: Mineral and Land Resources.

(講演テキスト)

Rovinove, C.H.: Remote-Sensing Potential in Basic-Data Acquisition. International Conference !on Water for Peace, Washington D.C., May 23-31, 1967.

United States Department of Interior: Remaks of Under Secretary of Interior Charls F. Luce at the Annual Meeting of the American Astronautical Society, Statlerl Hilton Hotel, Daras, Texas, May. 1, 1967.

\section{口 海上保安庁 水路部研究報告}

水路测量に抢ける解析空中三角測量について（水路 測量に扣ける写真測量の利用 [4]）杉浦邦朗, 束原和 雄, 小沢幸雄 昭和 41 年 2 号

Photogrammetric Investigation on the Upheava of Water Surface in the strait, Hayatomo Sato (Application of Photogrammetry to Hydrography 3) Kohei Ono, Toshio Kato and Kuniro Sugiura Report of Hydrographic Researches No. 1, May, 1966.

Hydrogaphic Review International Hydrogrphic Bureau Monaco

Reconnaissance Mapping from Aerial Photographs in unexplored country H.E. Saundess \& G.D. Blodgett. May 1956. Vol. XXXIII.

Photogrammetric Surveys for Nautical Charts B.G. Jones November 1955, Vol. XXXII.

Use of Aerial photographs for Revision of lnd lnformation on Nautical Charts H. R. Brooks November 1955, Vol. XXXII.

Low-water photography in Cobscook Bay. Maine B.G. Jones May 1958, Vol. XXXV.

Aerotriangutation Adjustment G.C. Tewinkel May 1958, Vol. XXXV. 